\title{
スタイラスを応用したウェットエンド化学*
}

株式会社イー・シー・シー・インターナショナル 技術サービス部岡 川 章 夫

\section{Application of Stylus on Wet End Chemistry}

\section{Akio Okagawa}

Technical Service Dev., ECC International Ltd.

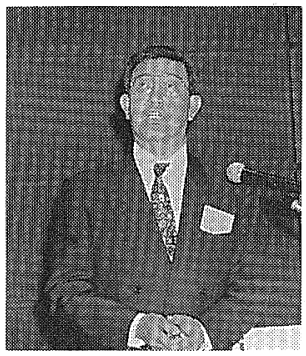

Drainage/retention aids have been used for many years to increase paper making productivity by controlling pulp freeness and raising pulp and filler retention. But it is well known that the improvement of drainage and retention brings on the deterioration of formation. As a method for preventing this situation the microparticle system was introduced about fifteen years ago. Its effect on neutral paper has been recognized and it somehow is able to repress formation deterioration.

ECCI has developed a new, more effective system, the Integra System, for drainage, retention and formation. This method uses two organic chemical components and is effective on both acidic and neutral papers. First chemical used is the emulsion of ultra high molecular polyacrylamide (Hydraid) whose molecular weight ranges from fifteen to twenty million. The second component is modified ligno-sulphonate (Stylus) with medium molecular weight. This presentation describes system future, the experimental results using standard pulps, pilot scale test result and the operational experience in a board mill.

Keywords: Retention/drainage aids, Formation, High molecular weight PAM, Hydraid, Ligno-sulphonate, Stylus

\section{1.ウェットエンドでの歩留・濾水剈の役割}

近年の紙料の多様化，特に古紙の利用率の桩大はウ エットエンド化学に大きな变革をもたらした。パルプ 中のファインや塡料の歩留を上げるための薬品, 濾水 性を向上させる薬品等の開発によりマシンの操業性が 大幅に改善された。初期の歩留剤は単純な凝集脷であ る。その代表的な薬品が硫酸バンドであり, 安価なこ とと応用範囲が広いことから世界中に広がり現在の酸

*平成 9 年度年次大会講演（講演 No.B 1-28）
性抄紙の基礎を築き上げた。しかしその後の各種機械 パルプの開発や古紙利用の拡大は硫酸バンドの応用に 限界があることが指摘され，1960 年代の中頃には合 成高分子の凝集剛の開発が始まり, 酸性抄紙の見直し に伴う中性抄紙の要求を満たすものとして歩留・濾水 剤の使用が一般的になってきた。

歩留・濾水剤の主な役割はパルプ紙料中の微細繊維 (ファイン) や填料粒子を長䋐維と伴に凝集させて歩 留を向上させると同時に，紙層構造形成過程で濾水性 を改善しマシン操業性を向上させ，生産性をあげるこ とにある。これを達成させる凝集のメカニズムは使用 
する薬品により粒子表面の電荷を中和させるコアギュ レーションと高分子の架橋によるフロッキュレーショ ンとに大別することができる。硫酸バンドや分子量の 小さい高荷電の高分子 (例えば poly-DMDAAC) な どは粒子表面の電荷を中和してファインや填料を凝集 させる。一方各種の水溶性ポリマーは粒子間を架橋し てフロックを形成する。最も一般的な合成高分子系の 歩留・濾水剂はポリアクリルアミドを骨格にし加水分 解, エステル化, 共重合などの手法によりアニオン, カチオンの電荷を持たせている。

微細纎維や填料の凝集と同時に長繊維分も凝集して フロックを形成するが，その大きさや形は添加するポ リマーの種類や添加量によって様々なものが出来る。 歩留が向上すると一般には地合が悪くなることは良く 知られている事実である。よい地合を作るにはパルプ や填料が紙層中に均一に分散されることが要求される。 分散と凝集は相反することであり両者を同時に満足さ せることは非常に困難である。しかもそれを一つの薬 品で達成させることは全く不可能である。従って地合 の低下が許容される範囲内での添加となり歩留剤の効 果を最大限に利用しているとは限らない。このジレン マを改善する方法として二つの薬品を使うデュアルシ ステムが開発された。それらの多くはカチオン性の高 分子と無機の微粒子を組合わせたものである。この様 なミクロパーティクルシステムの特徴は無機質の微粒 子を使うために抄紙機械への付着物の原因になりやす いことと薬品が比較的高価なことである。またそれら は中性抄紙の限られた条件下で効果を発揮するもので ある。

これらの問題点を解決すべく ECCI 社が開発した全 溶液系の “インテグラシステム”を以下に紹介する。

\section{2. エマルションポリマーとリグニン スルフォン酸}

PAM 系高分子の効率を最大限に引出すために分子 量を可能な限り大きくすること, 作業性を向上させる ために有効成分を出来るだけ高くすることの 2 つの課 題がある。ECCI 社はエマルションポリマーの開発に よりこれを達成した。“ハイドレイド”は有効成分 $25 \%$ のマルションで, 分子量も 1,500 万から 2,000 万と非常に高く電荷密度も様々なものがある。分子量 が非常に高いために既存の同様な PAM 系ポリマー 凝集剤と比較してファインや填料を凝集させるフロッ ク形成能力が高く歩留向上が著しい。従って通常の使 用条件では既存のポリマーに比較して添加量が少なく て同様の歩留効果が得られる。
“スタイラス”は木材中のリグニンを原料として水 に溶解する中程度の高分子量に調製された薬品である。 化学的にはポリリグニンスルフォン酸ソーダである。 リグニンスルフォン酸はその特性を利用して様々な分 野で利用されている。クラフトリグニンあるいはサル ファイトリグニンを原料として, 多糖類の分解・除去, 金属との錯体形成, 加水分解, 酸化反応, 高分子化等 などの変性を行うことにより様々な用途が開発されて いる。例えば染料の分散, 微粒子の凝集防止, 浮遊選 鉱助剂, 金属錯体形成能力を利用した工業用水処理剂, エマルションの分散安定剤, 飼料の結合剤などである。 さらにはリグニンと他のモノマーを共重合させた各種 のポリマーも開発されている。その内でリグニンスル フォン酸の分散能力に注目し PAM 系高分子で形成 されたフロックの分散安定に応用できないかと考えた。 様乃な思考錯誤を繰返しながら分子量やスルフォン化 度を変えてその効果を確認し, 歩留・濾水と地合を最 大限にバランスさせるようなリグニンスルフォン酸ソ ーダを開発することに成功した。

\section{3. インテグラシステムの開発}

\section{1 インテグラシステム}

上述のコンセプトから生まれた ECCI のデュアル システムをインテグラシステムと呼び，その特徴を列 記すると以下の通りである。

(1) 第一成分は分子量が 1,500 万から 2,000 万の超 高分子 PAM で, 有効成分が $25 \%$ エマルション である。

（2）第二成分は変性リグニンスルフォン酸ソーダで ある。

（3） $\mathrm{pH}$ 依存性が少なく，酸性・中性ともに使用可 能である。

（4）濾水・歩留の向上にも拘わらず地合が維持され る。

(5) ワイヤパートのみならずプレスパートでの脱水 効率が向上する。

（6）無機物質を含まない完全有機系であるのでデポ ッジト心配がない。

インテグラシステムでは始めに超高分子のハイドレ イドを抄紙原料に添加し紙料中の微細纎維や灰分をパ ルプと伴に大きなフロックを作り，それが加圧スクリ ーンを通過することにより細かなフロックに分断され る。その状態でス夕イラスを添加することによりその 分散効果が働いて柔らかな均一のフロック状態に安定 分散することによりワイヤー上での地合形成が達成さ れる。ミクロパーティクルシステムでは無機粒子によ 
る再凝集が起こり強固なフロックを形成するので地合 形成が困難になる。

\section{2 パイロットマシン試験}

酸性および中性条件でいわゆるミクロパーティクル システムとインテグラシステムの比較をパイロットマ シンで行った結果を示す。パイロットマシンはコンバ ーフローヘッドボックス付きのベルボンドフォーマを 使い抄速 $910 \mathrm{~m} / \mathrm{min}$.で実験した。それぞれのパルプ 配合比率を表 1 に示す。

パイロットマシンでの濾水特性を図 1 に示す。へッ ドボックスから下流に移動するに従って紙の水分が減 少していくが, ポリマー単独でスクリーンの前に添加 した場合は濾水にほとんど影響はない。しかしデュア ルシステムのポリマー・ベントナイト系およびインテ グラシステムでは明らかに濾水性が向上する。中でも インテグラシステムが最も濾水性が向上した。これは スタイラスによるフロックの均一化により紙層中の水 の透過が容易になったことと, リグニンの疎水性が働

表 1 パイロットマシン試験のパルプ配合

\begin{tabular}{c|c|c|c}
\hline & 中性紙料 1 & 中性紙料 2 & 酸性紙料 \\
\hline LBKP & 75 & 60 & 60 \\
\hline NBKP & 25 & 20 & 20 \\
\hline 古紙 & - & 20 & 20 \\
\hline 填料 & $20 \% \mathrm{CaCO}_{3}$ & $20 \% \mathrm{CaCO}_{3}$ & $20 \%$ カリン \\
\hline $\mathrm{pH}$ & 7.2 & 7.2 & 5.0 \\
\hline
\end{tabular}

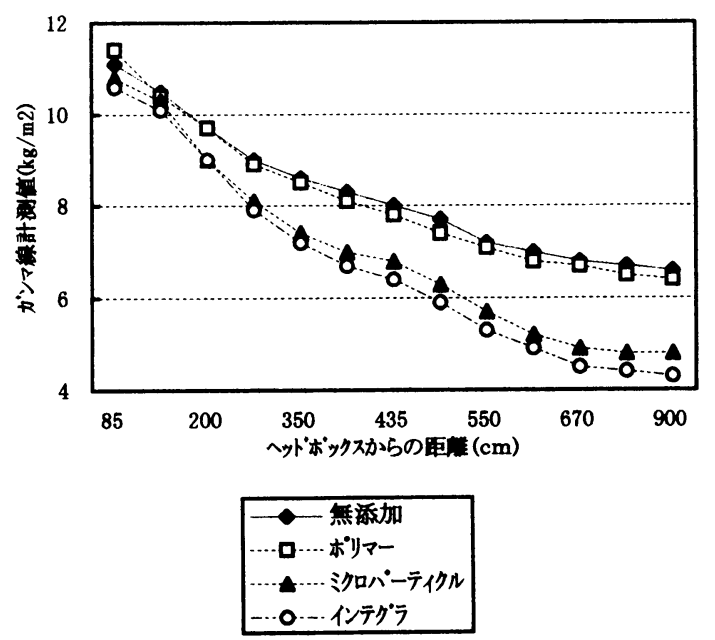

図 1 ガンマ線計測によるパイロットマシンでの滤水 曲線
いてフロックの水保持能力が低下したためと考えられ る。

図 2 にパルプおよび坥料のワンパスリテンションの 結果を示す。ポリマー単独の場合, 添加場所をスクリ ーン後，スクリーン前，さらにファンポンプ前のよう に順次上流に移動させていくと, 紙料がせん断応力に 曝されるに伴って歩留が減少していく。インテグラシ ステムでも同様な傾向を示し，スクリーン前後で八イ ドレイド・スタイラスを添加した場合が最も歩留が上 昇した。

通常の抄紙では濾水・歩留と地合は逆比例するもの である。図 3 に上記のそれぞれの条件における濾水と 地合の比較を示した。ポリマー単独添加の場合にスク リーン後へッドボックス直前の添加では地合を維持す ることはできるが濾水の向上が全く期待できない。更 に添加を上流に移動すれば，わずかな濾水の向上は見 られるが実用性はあまりない。

インテグラシステムでは地合の低下を最小限に抑え て，且つ歩留・滤水の向上を達成できることができる。 この際，ポリマーとリグニンの添加比率・添加場所を 適切に選択することにより, 濾水・歩留と地合を同時 に最適化することが可能である。

表 1 に示したパルプ配合を使って中性抄紙と酸性抄 紙でのインテグラシステムの効果を図 4，5に比較し た。中性抄紙ではポリマー単独でスクリーン前に添加 した場合, 濾水が全く向上しないが地合は良い。イン テグラシステムが明らかに濾水・歩留ともに優れてい る。地合についてもミクロパーティクルシステムと変 わりなく, 地合維持の効果が発揮されている。一方酸 性抄紙ではポリマー単独, ミクロパーティクルシステ ム共に濾水は改善されるどころか反対に悪影響を及ほ す。歩留・地合を維持しながら濾水を向上できるのが インテグラシステムの特徴である。

\section{4. 応用事例}

\section{1 板紙操業経験}

$100 \%$ 古紙 (段古紙, 新聞古紙, 上質古紙の混合) を原料として坪量 $488 \mathrm{~g} / \mathrm{m}^{2}$, 抄速 $152 \mathrm{~m} / \mathrm{min}$ で板紙 を生産している工場でのポリマー単独とインテグラシ ステムでの操業経験を比較した。代表的な結果として 円網バットの水位とリール巻取り速度を図 6,7 に示 す。ブリットジャーによる歩留測定やショッパーリグ ラー濾水計での測定はポリマー単独の方が良い結果示 したが，罒からも明白なように実機操業ではバットの 水位が下がり,リール巻取り速度も上昇しインテグラ システムの効果を確認することができた。 

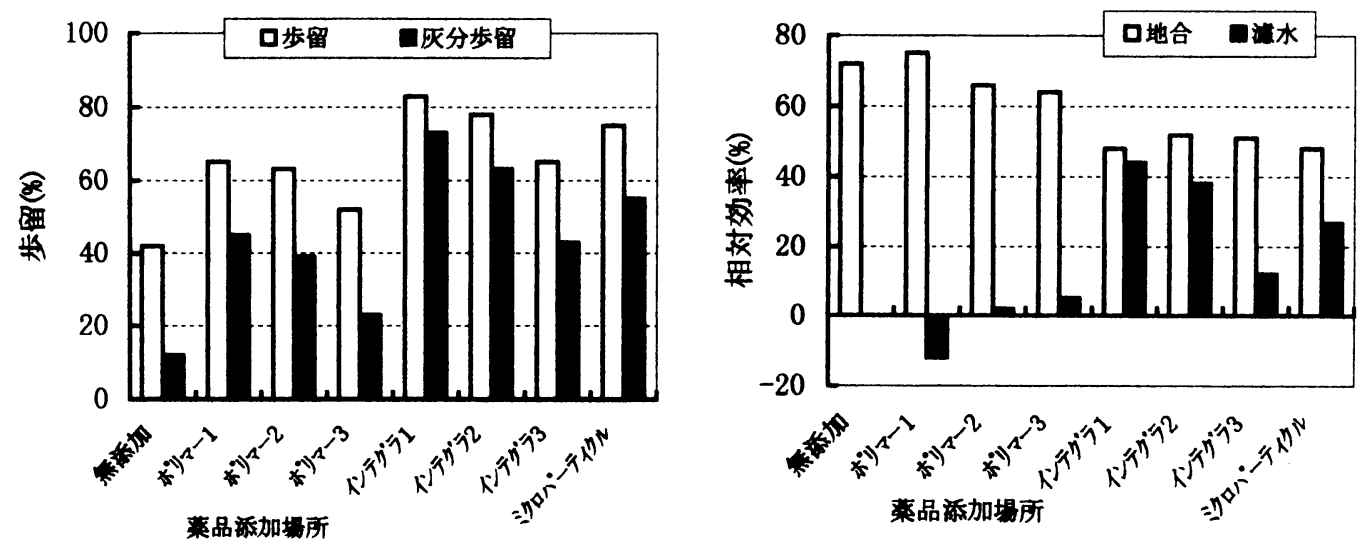

\begin{tabular}{|c|c|c|c|}
\hline & フアンポンプ前 & ス夘ーン前 & スクリーン後 \\
\hline ポリマー 1 & & & М仆レ仆 \\
\hline ポリマー 2 & & M仆レ仆 & \\
\hline 米师マ 3 & ハ仆レ仆 & & \\
\hline 价グラ 1 & & M仆 V作 & 双们 \\
\hline 价テグラ 2 & ハイドレト & & 双份 \\
\hline インテグラ 3 & ハ仆レ仆 & 不行 & \\
\hline
\end{tabular}

図 $2 \& 3$ パイロットマシンでの薬品添加場所と歩留，灰分歩留（左）および濾水・地合（右）
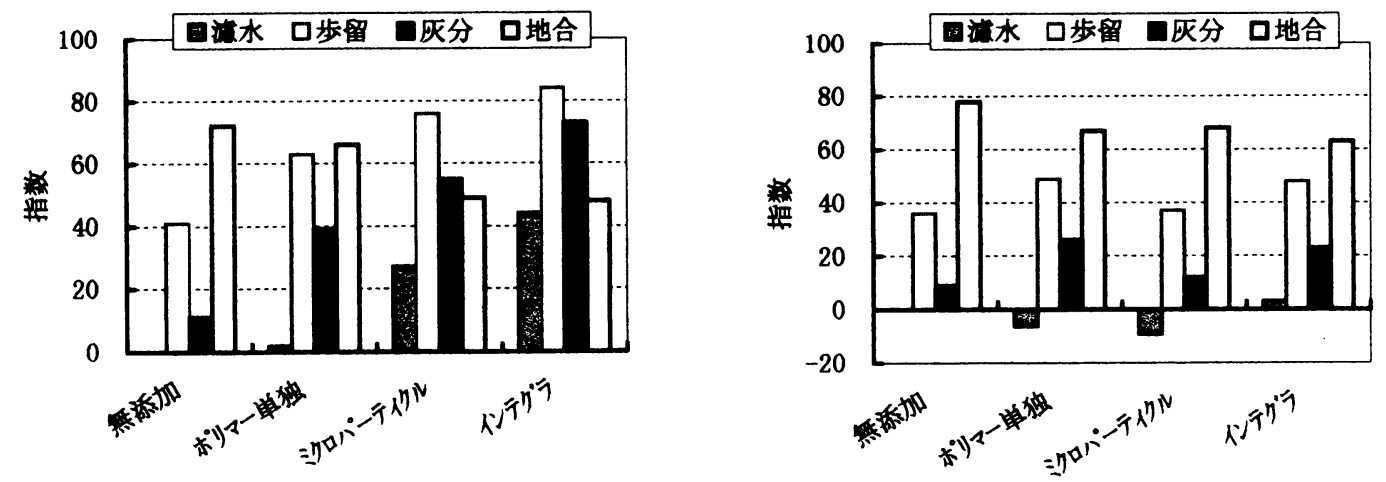

図 4\&5 パイロットマシンでの中性抄紙（左）と酸性抄紙（右）の比較
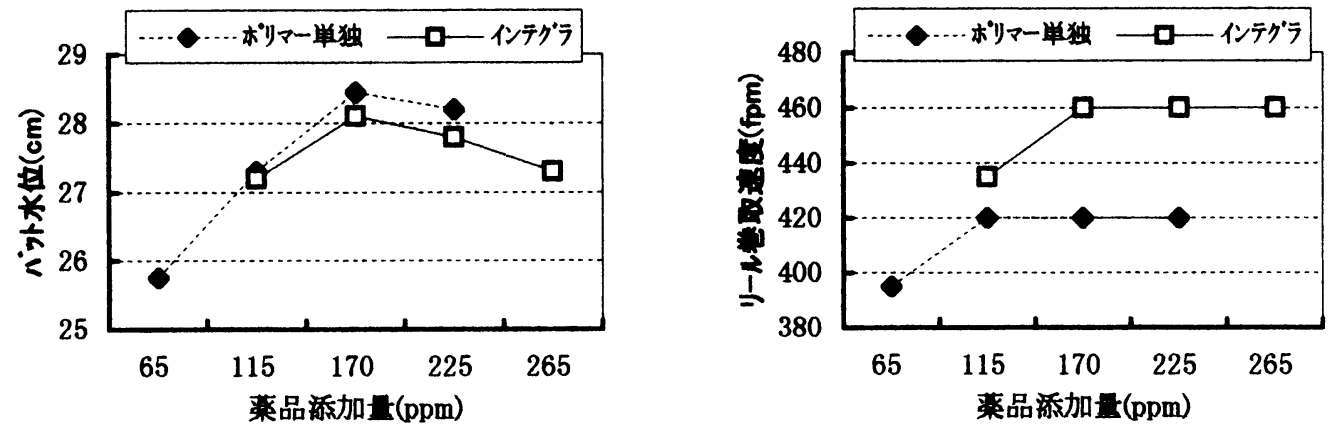

図 $6 \& 7$ 板紙マシンのバット平均水位とリール巻取り速度 


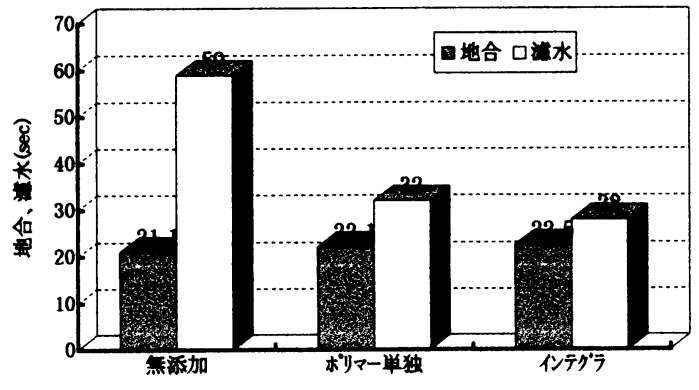

図 8 新聞用紙マシンでの濾水・地合に及ぼすスタイ ラスの効果

\section{2 新聞用紙操業経験}

北米での典型的な新聞用紙工場でインテグラシステ ムを使っての操業では地合を維持しながら濾水性を著 しく向上させることができた。パルプ配合は $25 \% \mathrm{NKP}$
に残りは GP, TMP, DIPで構成されており，8\%の カオリン填料, $\mathrm{pH}=4.8$, ベロイト社ベルベイマシン, 抄速 $1,020 \mathrm{~m} /$ 分で操業している。この場合の地合と 濾水に及ぼすス夕イラスの効果を図 8 に示す。

\section{5. まと め}

ここで紹介した ECCI が新たに開発した二成分系の インテグラシステムは, 従来のデュアルシステムの代 表的なミクロパーティクルシステムに比較しても更に 効率が良く米国・欧州ではすでに 2 年前から広範囲な 抄紙系で実用化されている。日本国内でも板紙のみな らず中質紙や新聞用紙の各方面から注目されている新 しい技術である。超高分子エマルションとリグニンス ルフォン酸ソーダの組合せによるこのシステムは中性 抄紙と酸性抄紙のいずれの条件でも同様な効果が期待 できる画期的なシステムである。 